\title{
AN INTRODUCTION TO A HOMOGENEOUS CHARGE COMPRESSION IGNITION ENGINE
}

\author{
A.A. Hairuddin ${ }^{1,2^{*}}$, A.P. Wandel ${ }^{1}$ and T. Yusaf ${ }^{1}$ \\ ${ }^{1}$ Faculty of Health, Engineering and Sciences, \\ School of Mechanical and Electrical Engineering, \\ University of Southern Queensland, Toowoomba, 4350 QLD, Australia \\ ${ }^{2}$ Department of Mechanical and Manufacturing Engineering, Faculty of Engineering, \\ Universiti Putra Malaysia, Malaysia. \\ *Email: Ahziz@upm.edu.my \\ Phone: +60389466331
}

\begin{abstract}
Homogeneous charge compression ignition (HCCI) engine technology is relatively new and has not matured sufficiently to be commercialised compared with conventional engines. It can use spark ignition or compression ignition engine configurations, capitalizing on the advantages of both: high engine efficiency with low emissions levels. HCCI engines can use a wide range of fuels with low emissions levels. Due to these advantages, HCCI engines are suitable for use in a hybrid engine configuration, where they can reduce the fuel consumption even further. However, HCCI engines have some disadvantages, such as knocking and a low to medium operating load range, which need to be resolved before the engine can be commercialised. Therefore, a comprehensive study has to be performed to understand the behaviour of HCCI engines.
\end{abstract}

Keywords: Diesel; HCCI; gasoline; natural gas; hydrogen.

\section{INTRODUCTION}

The greenhouse effect is a worldwide issue as more and more greenhouse gases are released into the atmosphere, leading to global climate change [1-6]. The effects include an increase in temperature, unstable weather and rising ocean levels, resulting from ice melting at the North and South Poles [7-9]. This has become a global issue. Members of the Copenhagen Climate Conference in December 2009 [10] were unable to reach an agreement on climate change. The increase of surface air temperature due to global warming has been simulated by Rob [11] from NASA (see Figure 1), showing an increase in surface air temperature from 1960 to 2060. According to the report of the World Resources Institute [12], transportation accounted for about $14 \%$ of the global greenhouse gases in 2000, making it a major contributor to global climate change and equivalent to $18 \%$ of global $\mathrm{CO}_{2}$ emissions. Thus, it is imperative to minimise the emissions level from the transportation sector. To counter this issue, many automotive manufacturers are developing electric, fuel-cell or hybrid engines [13-15]. An electric vehicle is driven by an electric motor, with the energy supplied by a high capacity battery stored in the car trunk or under the car body. The operation of the fuel-cell engine is similar to the electric vehicle, using an electric motor to drive the wheel. However, the difference is in the electricity generation method. Most fuel-cell driven vehicles use hydrogen and oxygen to generate electricity [16, 17]. Then, this electric 
energy will be stored in a high-capacity battery and is used to drive the electric motor. The hybrid vehicle uses a combination of the conventional internal combustion (IC) engine and electric motor. The IC engine could be a spark ignition (SI) or compression ignition (CI) engine, which is connected to the electric motor either in parallel or in series to drive the wheel. A high-capacity battery is again used to power the electric motor. Therefore, in summary, the vehicle is driven by two or more power sources in hybrid configurations. Table 1 summarises the advantages and disadvantages of these technologies, where the high implementation cost related to each of them leads to a slow commercialisation rate. Thus, an interim solution is required to improve the current IC engines at a low implementation cost.

Table 1. Comparison of newly developed engine technology [18].

\begin{tabular}{|c|c|c|}
\hline Engine Type & Advantages & Disadvantages \\
\hline Hydrogen Fuel Cell & $\begin{array}{ll}\text { - } & \text { Compact design } \\
\text { - } & \text { relatively long } \\
& \text { operating life } \\
\text { - } & \text { high efficiency } \\
\text { - low temperature } & \text { loperation. }\end{array}$ & $\begin{array}{ll}\text { - } & \text { Higher loads reduce } \\
\text { efficiency considerably } \\
\text { - } \\
\text { - high energy cost } \\
\text { - high manufacturing cost } \\
\text { heavy auxiliary } \\
\text { equipment } \\
\text { - complex heat and water } \\
\text { management } \\
\text { - } \text { safety issues }\end{array}$ \\
\hline Electric & $\begin{array}{l}\text { - No fuel } \\
100 \% \text { emissions free at } \\
\text { the vehicle } \\
\text { (substantially reduced } \\
\text { emissions overall) } \\
\text { - fewer moving parts to } \\
\text { wear out. }\end{array}$ & $\begin{array}{ll}\text { - } & \text { Limited operating } \\
& \text { battery ranges } \\
\text { - } & \text { long recharge time } \\
\text { - } & \text { battery size and weight } \\
\text { issues } \\
\text { - high battery } \\
\text { replacement costs } \\
\text { - limited charging } \\
\text { facilities }\end{array}$ \\
\hline Hybrid & $\begin{array}{l}\text { - Lower emissions level } \\
\text { - better fuel economy } \\
\text { over conventional } \\
\text { engines. }\end{array}$ & $\begin{array}{l}\text { - Unachievable break- } \\
\text { even point before } \\
\text { replacing the battery } \\
\text { - high and costly } \\
\text { maintenance } \\
\text { - battery size adds extra } \\
\text { weight to the vehicle }\end{array}$ \\
\hline
\end{tabular}

\section{HOMOGENEOUS CHARGE COMPRESSION IGNITION ENGINES}

IC engines are widely used in numerous applications: vehicle engines, power generation and ships. The emissions generated from these applications have a major impact on the environment, so alternative solutions have been investigated to achieve low emissions levels $[12,13,18-21]$. A new mode of combustion is being sought in order to reduce the emissions levels from these engines: a potential candidate is the Homogeneous Charge Compression Ignition (HCCI) engine. Figure 2 shows the differences among SI, CI and 
HCCI engines, where SI engines have a spark plug to initiate combustion with a flame front propagating across the combustion chamber. CI engines have a fuel injector to inject the diesel and combustion takes place in a compressed hot air region. HCCI engines, on the other hand, have no spark plug or fuel injector and the combustion starts spontaneously in multiple locations. High engine efficiency can be achieved with low $\mathrm{NO}_{x}$ and soot emissions. In HCCI combustion, a homogeneous mixture of air and fuel is compressed until auto-ignition occurs near the end of the compression stroke, followed by a combustion process that is significantly faster than either CI or SI combustion [2124]. Epping et al. [25] and Christensen and Johansson [26] reported that HCCI technology, using iso-octane as a fuel, has improved engine efficiency by as much as $37 \%$ given a high compression ratio (18:1) and maintains low emissions levels. The efficiency and compression ratio are in the range of CI engines. The technology can be implemented by modifying either SI or CI engines using any fuel or combination of fuels. The air/fuel mixture quality in HCCI engines is normally lean, it auto-ignites in multiple locations and is then burned volumetrically without discernible flame propagation [27]. Combustion takes place when the homogeneous fuel mixture has reached the chemical activation energy and is fully controlled by chemical kinetics [28] rather than spark or injection timing.

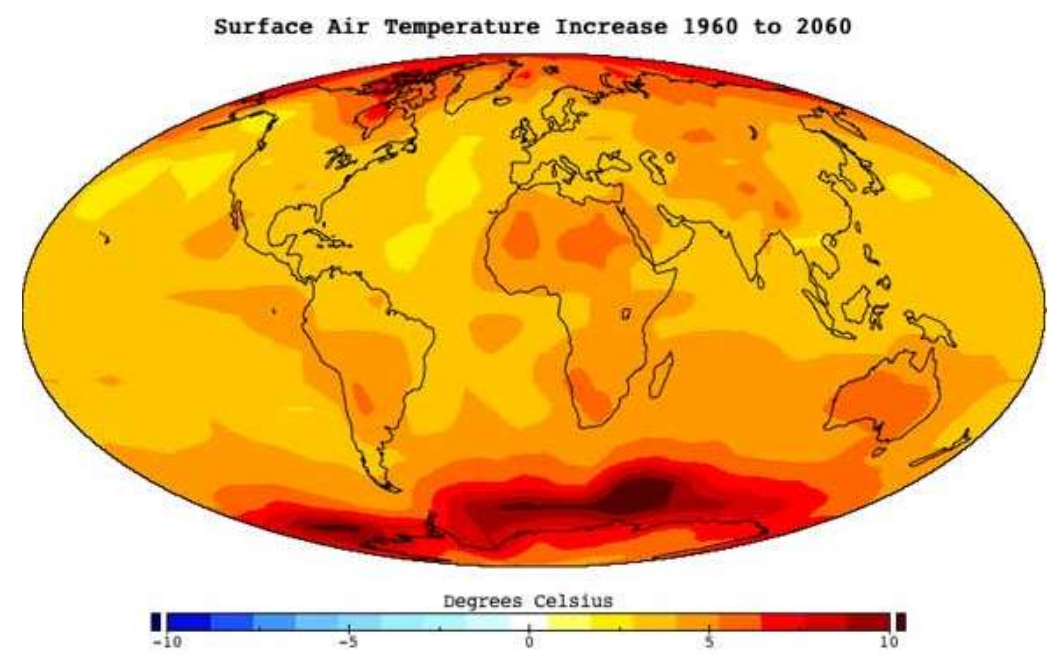

Figure 1. Simulated surface air temperature increase by the year 2060 [11].

Since the mixture is lean and is fully controlled by chemical kinetics, there are new challenges in developing HCCI engines: difficulty controlling the auto-ignition of the mixture and the heat release rate at high load operation, achieving a cold start, meeting emission standards and controlling knock [29, 30]. The advantages of using HCCI technology in IC engines are:

1. High efficiency relative to SI engines - approaching the efficiency of CI engines due to the ability of these engines to use a high compression ratio (CR) and fast combustion $[31,32]$;

2. The ability to operate with a wide range of fuels [32-34]; and

3. The ability to be used in any engine configuration: automobile engines, stationary engines, heavy duty engines or small engines [25, 35, 36]. 

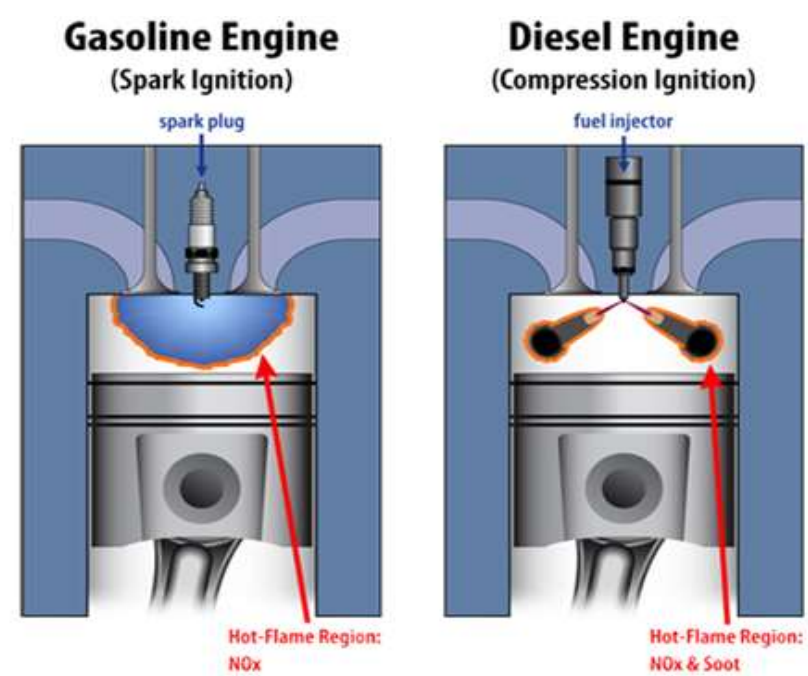

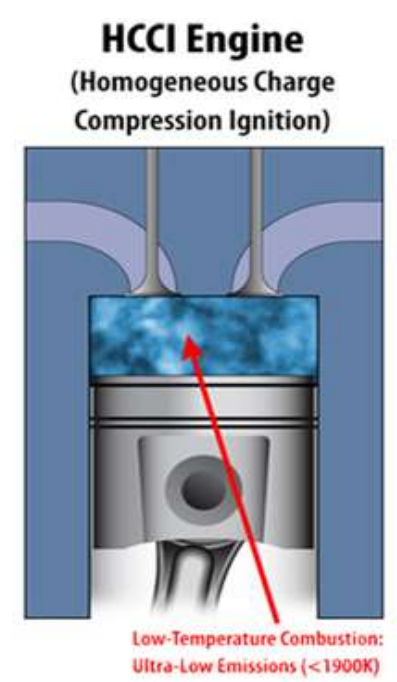

Figure 2. The differences among SI, CI and HCCI engines, reproduced from Pitz and Westbrook [37].

On the other hand, HCCI engines have some disadvantages such as high levels of unburned hydrocarbons (UHC) and carbon monoxide (CO) [29, 38, 39]. Knocking also occurs under certain operating conditions and reduces the operating range of the engine [29, 38, 40-42]. Emissions regulations are becoming more stringent and $\mathrm{NO}_{x}$ and soot emissions levels in HCCI engines have been greatly reduced without sacrificing efficiency, which is close to that of CI engines [38]. However, knocking is still the major issue because of its sudden onset and it results in a bad engine performance. Knocking is due to premature combustion, where the ignition takes place before the piston reaches top dead centre (TDC) and it reduces engine reliability due to high vibration effects. Recently, hybrid engines have been developed by many automotive manufacturers due to their advantages, and the HCCI engine has the potential to replace the IC engine used in a hybrid configuration, which could reduce the emissions levels further. Thus, it is important to investigate the HCCI engine's performance because it can be used in the near future.

\section{State of the Art Current Internal Combustion Engines}

Producing homogeneous mixtures to achieve near-complete combustion is a common goal that will lead to the development of low-polluting engines. Some technologies including Fuel-Stratified Injection (FSI), Turbo-Stratified Injection (TSI) and HCCI are used to improve the combustion efficiencies by introducing the homogeneous mixture. FSI and TSI are commercially used by Volkswagen Aktiengesellschaft (AG), which consists of other daughter companies: Audi, Skoda, Seat, Bugatti, Lamborghini, Bentley and Scania [43]. FSI uses direct injection fuel with high injection pressure, where the evaporating fuel has a significant cooling effect on the cylinder charge [44]. This effect helps in reducing the knock and therefore a higher compression ratio can be used. The air enters the combustion chamber at a certain angle by using a moveable flap inside the intake manifold [45], while fuel is directly injected during the intake stroke. The fuel injector is located close to the inlet valve in the cylinder head. With the help of the piston crown design, the air will experience tumbling effects inside the chamber. This in turn will help the fuel to mix homogeneously with air. TSI engines, on the other hand, 
use a high intake pressure (using multipoint injectors) on an FSI engine [46]. This allows the fuel to mix homogeneously with the air during the compression stroke. The pressurised intake air will assist the combustion and therefore produce better efficiency, allowing smaller engines to be built with power and torque similar to that of bigger engines. The first engine to use direct injection technology in a stratified charge engine was the Texaco combustion process [47], as reported by Takagi [48]. HCCI engines can be considered as new technology [49] even though the research was initially undertaken by Onishi et al. [50]. Researchers worldwide are investigating HCCI engines, as this technology has not yet been sufficiently developed and commercially available. General Motors (GM) has unveiled a prototype car with a gasoline HCCI engine, which could cut fuel consumption by $15 \%$ [51]. The engine is able to virtually eliminate $\mathrm{NO}_{x}$ emissions and to lower throttling losses, which improves fuel economy.

\section{Gasoline Operated HCCI Engines}

Gasoline could be operated in HCCI mode on its own; however, it would be unstable in a high load operating range. High load difficulties are a common problem for HCCI engines regardless of the fuel being used. The solution to this issue for gasoline fuel is to operate the engine in HCCI mode in the medium load range, and switch to SI mode in the high load range [52]. Wang et al. [53] studied the gasoline HCCI engine with secondary injections and reported that the operating load range could be extended by using a two-zone HCCI mode, which utilises secondary injections. However, the twozone mode yields higher $\mathrm{NO}_{\mathrm{x}}$ emissions due to a fuel-rich zone that develops in the chamber.Iso-octane is generally used as a gasoline surrogate fuel in numerical studies due to its high octane rating. Higher octane numbers cause difficulties in achieving the HCCI mode [54]. Thus the ignition has to be controlled using other means. The use of high octane number fuels, such as gasoline, in a low CR engine allows the engine to be switchable to SI mode in a high load range [55]. It is found that a high CR engine (as high as 18:1) has advantages by producing ultra-low $\mathrm{NO}_{\mathrm{x}}$ emissions (1ppm) and higher thermal efficiency (43\%) at a fixed operating condition [56].

Gasoline can also be mixed with diesel to operate in HCCI mode. A study by Kim and Lee [57] on the effect of multiple fuels on emissions showed that the combination of diesel and gasoline (diesel is direct injected while gasoline is port injected) is an effective way to reduce $\mathrm{NO}_{\mathrm{x}}$ levels, with the increase of the premixed ratio. The premixed ratio is defined as the energy of premixed (port injected) fuel to the energy of total fuel (direct and port injected). Zhong et al. [58] also studied the effect of blended fuels between gasoline and diesel, and reported that $\mathrm{UHC}$ and $\mathrm{NO}_{\mathrm{x}}$ were significantly reduced throughout the HCCI engine load ranges. The purpose of blending gasoline and diesel is that gasoline has a high volatility and is easy to vaporise, and can thus be used to form a homogeneous mixture. Gasoline also has a high octane number, where higher numbers show higher resistivity to knocking. Diesel, on the other hand, has good ignitability and fast combustion due to its high cetane number. Table 2 compares the characteristics of the gasoline and diesel fuels, where for the selected gasoline (octane number 98) the heating values are very similar for the two fuels.

\section{Natural Gas and Hydrogen with Diesel in HCCI mode}

The combination of natural gas or hydrogen with diesel is reported to yield low emissions and to some extent increase the engine efficiency, either in HCCI or CI 
combustion mode [59-63]. Diesel alone is not suitable for HCCI engines due to its low volatility and high propensity to auto-ignite, while natural gas has a high resistance to auto-ignition, as reported by Kong [64]. Combinations of high octane number fuels (such as natural gas and hydrogen) with high cetane number fuels (such as diesel) are able to increase the engine durability, and under certain operating conditions reduce emissions levels such as soot, $\mathrm{HC}, \mathrm{CO}$ and $\mathrm{NO}_{x}$ [65-68]. It was also reported that these combinations have a high thermal efficiency under early injection timing [66, 68]. Fuels with a higher octane number have better resistance to knocking, while fuels with a higher cetane number have a shorter ignition delay time, thus providing more time for the fuel to complete the combustion. Therefore, a combination of both (high cetane number fuels and high octane number fuels) provides a soft engine run [65], whereby the mixture can be operated at high CR and has a longer combustion duration.

Table 2. Characteristics of gasoline and diesel fuels [57].

\begin{tabular}{lll}
\hline & Gasoline & Diesel \\
\hline Octane number & 98 & - \\
Cetane number & - & 54 \\
Higher heating value $(\mathrm{kJ} / \mathrm{kg})$ & 47300 & 44800 \\
Lower heating value $(\mathrm{kJ} / \mathrm{kg})$ & 44000 & 42500 \\
Boiling point $(\mathrm{K})$ & 468 & 553 \\
Density $\left(\mathrm{kg} / \mathrm{m}^{3}\right)$ & 750 & 814 \\
Stoichiometric air-fuel ratio & 14.6 & 14.5 \\
\hline
\end{tabular}

Table 3. Diesel properties compared to hydrogen and natural gas $[62,63,69,70]$.

\begin{tabular}{llll}
\hline Properties & Diesel & Hydrogen & Natural Gas \\
\hline Main component & $\mathrm{C}_{12} \mathrm{H}_{23}$ & $\mathrm{H}_{2}$ & Methane $\left(\mathrm{CH}_{4}\right)$ \\
Auto-ignition temperature $(\mathrm{K})$ & 553 & 858 & 923 \\
Lower heating value $(\mathrm{MJ} / \mathrm{kg})$ & 42.5 & 119.93 & 50 \\
Density $\left(\mathrm{kg} / \mathrm{m}^{3}\right)$ & $833-881$ & 0.08 & 0.862 \\
Molecular weight $(\mathrm{g} / \mathrm{mol})$ & 170 & 2.016 & 16.043 \\
Flammability limits in air (vol\%) (LFL-UFL) & $0.7-5$ & $4-75$ & $5-15$ \\
Flame velocity (m/s) & 0.3 & $2.65-3.25$ & 0.45 \\
Specific gravity & 0.83 & 0.091 & 0.55 \\
Boiling point $(\mathrm{K})$ & $453-653$ & 20.2 & 111.5 \\
Cetane number & $40-60$ & - & - \\
Octane number & 30 & 130 & 120 \\
$\mathrm{CO}_{2}$ emissions $(\%)$ & 13.4 & 0 & 9.5 \\
Diffusivity in air $\left(\mathrm{cm}^{2} / \mathrm{s}\right)$ & - & 0.61 & 0.16 \\
Min ignition energy $(\mathrm{mJ})$ & - & 0.02 & 0.28 \\
\hline
\end{tabular}

Hydrogen has a high octane number (approximately 130) and a high Lower Heating Value (LHV) $(119.93 \mathrm{MJ} / \mathrm{kg})$. Its combination with diesel helps to increase engine efficiency [2, 61, 71, 72] and control the auto-ignition point in HCCI engines [65]. Natural gas, on the other hand, has a higher auto-ignition temperature and it can be used in high CR engines [73]. Table 3 compares the physical and chemical properties of diesel with natural gas and hydrogen. From Table 3, hydrogen has the highest LHV or lower calorific value compared to both diesel and natural gas, which means that it 
releases a high amount of energy during combustion and thus produces the highest flame speed. A wide range of the flammability limits in air allows a wider range of engine power outputs through changes in the mixture equivalence ratio. Flammable mixtures of hydrogen can go from as lean as $\lambda=10$ to as rich as $\lambda=0.14$ [63], where $\lambda$ is the air-to-fuel ratio actual divided by the air-to-fuel ratio stoichiometric.

\section{CONCLUSIONS}

Therefore, it is feasible to use gasoline, diesel, natural gas, hydrogen or a combination of those in HCCI engines, because the engine can be operated with a wide range of fuels. From the practicality point of view, the HCCI engine can be used in a hybrid configuration, where it might help reduce the fuel consumption even further. Many studies show that the HCCI engine has low $\mathrm{NO}_{x}$ emissions, soot and particulates. However, HCCI engines still have unresolved issues with knocking and high levels of unburned $\mathrm{HC}$ and $\mathrm{CO}$ emissions. Further studies have to be performed in order to solve these remaining problems. To achieve this, the numerical method is proposed for early study because it has a great advantage over experiments in terms of cost and time. To this end, a simulation model has been developed to investigate the combustion behaviour and, once completed, it has to be validated against experiments.

\section{ACKNOWLEDGEMENTS}

The author would like to thank University of Southern Queensland (USQ) and Universiti Putra Malaysia (UPM) for providing support and laboratory facilities. Also, great thanks go to the Ministry of Education, Malaysia for financial support.

\section{REFERENCES}

[1] Kamil M, Rahman MM, Bakar RA. Performance evaluation of external mixture formation strategy in hydrogen fueled engine. Journal of Mechanical Engineering and Sciences. 2011;1:87-98.

[2] Hamada KI, Rahman MM, Abdullah MA, Bakar RA, A. Aziz AR. Effect of mixture strength and injection timing on combustion characteristics of a direct injection hydrogen-fueled engine. International Journal of Hydrogen Energy. 2013;38:3793-801.

[3] Hamada KI, Rahman MM, Aziz ARA. Parametric study of instantaneous heat transfer based on multidimensional model in direct-injection hydrogen-fueled engine. International Journal of Hydrogen Energy. 2013;38:12465-80.

[4] Hamada KI, Rahman MM, Aziz ARA. Influence of engine speed and mixture strength on instantaneous heat transfer for direct injection hydrogen fuelled engine. Energy Education Science and Technology Part A: Energy Science and Research. 2012;30:153-72.

[5] Kamil M, Rahman MM, Bakar RA. Modeling of common rail fuel injection system of four cylinder hydrogen fueled engine. Journal of Engineering and Technology. 2010;1:42-52.

[6] Kamil M, Rahman MM, Bakar RA, Kadirgama K. Modeling of SI engine for duel fuels of hydrogen, gasoline and methane with port injection feeding system. Energy Education Science and Technology Part A: Energy Science and Research. 2012;29:1399-416. 
[7] Bates B, Kundzewicz ZW, Wu S, Palutikof J. Climate change and water: Intergovernmental Panel on Climate Change; 2008.

[8] Graham RL, Turner MG, Dale VH. How increasing CO2 and climate change affect forests. BioScience. 1990:575-87.

[9] Houghton JT, Ding Y, Griggs DJ, Noguer M, van der Linden PJ, Dai X, et al. Climate change 2001: the scientific basis2001.

[10] Bodansky D. The Copenhagen climate change conference: a postmortem. American Journal of International Law. 2010;104:230-40.

[11] Rob G. Watching Earth's Climate Change in the Classroom. 2005.

[12] Jonathan P. Responses to questions on the design elements of a mandatory market-based greenhouse gas regulatory system. World Resources Institute, Washington. 2006.

[13] Aziz Hairuddin A, Wandel AP, Yusaf T. Effect of different heat transfer models on a diesel homogeneous charge compression ignition engine. International Journal of Automotive and Mechanical Engineering. 2013;8:1292-304.

[14] Kamil M, Rahman MM, Bakar RA. Integrated simulation model for composition and properties of gases in hydrogen fueled engine. International Journal of Automotive and Mechanical Engineering. 2013;8:1242-155.

[15] Kamil M, Rahman MM, Bakar RA. An integrated model for predicting engine friction losses in internal combustion engines. International Journal of Automotive and Mechanical Engineering. 2014;9:1695-708.

[16] Ogden JM, Steinbugler MM, Kreutz TG. A comparison of hydrogen, methanol and gasoline as fuels for fuel cell vehicles: implications for vehicle design and infrastructure development. Journal of Power Sources. 1999;79:143-68.

[17] Trimm DL, Önsan ZI. Onboard fuel conversion for hydrogen-fuel-cell-driven vehicles. Catalysis Reviews. 2001;43:31-84.

[18] Chan C. The state of the art of electric and hybrid vehicles. Proceedings of the IEEE. 2002;90:247-75.

[19] Cho HM, He B-Q. Spark ignition natural gas engines-A review. Energy Conversion and Management. 2007;48:608-18.

[20] Taylor AM. Science review of internal combustion engines. Energy Policy. 2008;36:4657-67.

[21] Mohanamurugan S, Sendilvelan S. Emission and combustion characteristics of different fuel In A HCCI engine. International Journal of Automotive and Mechanical Engineering. 2011;3:279-92.

[22] Raitanapaibule K, Aung K. Performance predictions of a hydrogen-enhanced natural gas HCCI engine. International Mechanical Engineering Congress and Exposition: American Society of Mechanical Engineers; 2005. p. 289-94.

[23] Gharehghani A, Hosseini R, Yusaf T. Investigation of the effect of additives to natural gas on heavy-duty si engine combustion characteristics. Journal of Mechanical Engineering and Sciences. 2013;5:677-87.

[24] Noor MM, Wandel AP, Yusaf T. The simulation of biogas combustion in a mild burner. Journal of Mechanical Engineering and Sciences. 2014;6:995-1013.

[25] Epping K, Aceves S, Bechtold R, Dec J. The potential of HCCI combustion for high efficiency and low emissions. SAE Technical Paper No. 2002-01-1923; 2002.

[26] Christensen M, Johansson B. Influence of mixture quality on homogeneous charge compression ignition. SAE Technical Paper No. 982454; 1998. 
[27] Kong S-C, Reitz RD. Use of detailed chemical kinetics to study HCCI engine combustion with consideration of turbulent mixing effects. Journal of Engineering for Gas Turbines and Power. 2002;124:702-7.

[28] Najt PM, Foster DE. Compression-ignited homogeneous charge combustion. SAE Technical Paper No. 830264; 1983.

[29] Kong S-C, Reitz RD. Numerical study of premixed HCCI engine combustion and its sensitivity to computational mesh and model uncertainties. Combustion Theory and Modelling. 2003;7:417-33.

[30] Soylu S. Examination of combustion characteristics and phasing strategies of a natural gas HCCI engine. Energy conversion and management. 2005;46:101-19.

[31] Killingsworth NJ, Aceves SM, Flowers DL, Krstic M. A simple HCCI engine model for control. Computer Aided Control System Design, 2006 IEEE International Conference on Control Applications. IEEE International Symposium on Intelligent Control. 2006, p. 2424-9.

[32] Mack JH, Aceves SM, Dibble RW. Demonstrating direct use of wet ethanol in a homogeneous charge compression ignition (HCCI) engine. Energy. 2009;34:782-7.

[33] Aceves S, Flowers D. Engine shows diesel efficiency without the emissions. Lawrence Livermore National Laboratory. 2004.

[34] Christensen M, Johansson B, Einewall P. Homogeneous charge compression ignition (HCCI) using iso-octane, ethanol and natural gas - A comparison with spark ignition operation. SAE Paper 971676; 1997.

[35] Hiltner J, Fiveland S, Agama R, Willi M. System efficiency issues for natural gas fueled HCCI engines in heavy-duty stationary applications. SAE Technical Paper; 2002.

[36] Kawano D, Suzuki H, Ishii H, Goto Y, Odaka M, Murata Y, et al. Ignition and combustion control of diesel HCCI. SAE Technical Paper No. 2005-01-2132; 2005.

[37] Pitz JW, Westbrook CK. Combustion Chemistry. 2011.

[38] Swami Nathan S, Mallikarjuna J, Ramesh A. An experimental study of the biogas-diesel HCCI mode of engine operation. Energy Conversion and Management. 2010;51:1347-53.

[39] Yap D, Peucheret S, Megaritis A, Wyszynski M, Xu H. Natural gas HCCI engine operation with exhaust gas fuel reforming. International Journal of Hydrogen Energy. 2006;31:587-95.

[40] Andreae MM, Cheng WK, Kenney T, Yang J. On HCCI engine knock. SAE Technical Paper No. 2007-01-1858; 2007.

[41] Jun D, Ishii K, lida N. Autoignition and combustion of natural gas in a 4 Stroke HCCI engine. JSME International Journal Series B. 2003;46:60-7.

[42] Yelvington PE, Green WH. Prediction of the knock limit and viable operating range for a homogeneous-charge compression-ignition (HCCI) engine. SAE Technical Paper No. 2003-01-1092; 2003.

[43] Volkswagen. Volkswagen Aktiengesellschaft - 2009 Annual Report. Wolfsburg; 2009.

[44] Audi. 2012.

[45] Wurms R, Grigo M, Hatz W. Audi FSI technology improved performance and reduced fuel consumption. ATA-TORINO-. 2003;56:118-25.

[46] Böhme J, Jung M, Fröhlich G, Pfannerer D, Märkle T, Felsmann C. The new 1.8 1 four cylinder T-FSI engine by Audi. MTZ worldwide. 2006;67:2-5. 
[47] Barber E, Reynolds B, Tierney W. Elimination of combustion knock-Texaco combustion process. SAE Technical Paper NO. 510173; 1951.

[48] Takagi Y. A new era in spark-ignition engines featuring high-pressure direct injection. Symposium (International) on Combustion. 1998; 27(2),2055-68.

[49] Yao M, Zheng Z, Liu H. Progress and recent trends in homogeneous charge compression ignition (HCCI) engines. Progress in Energy and Combustion Science. 2009;35:398-437.

[50] Onishi S, Jo SH, Shoda K, Do Jo P, Kato S. Active thermo-atmosphere combustion (ATAC)-a new combustion process for internal combustion engines. SAE Technical paper NO. 790501; 1979.

[51] Premier A. HCCI could cut fuel consumption by 15\%. Advanced Materials and Processes. 2007, 11,27.

[52] Fengjun G, Yingnan G, Fafa L, Hua L, Honggang J, Manzhi T. Control of HCCI engine fueled with gasoline with electro-hydraulic variable valve system. 2nd International Asia Conference on Informatics in Control, Automation and Robotics. 2010, p. 250-3.

[53] Wang Z, Shuai S-J, Wang J-X, Tian G-H. A computational study of direct injection gasoline HCCI engine with secondary injection. Fuel. 2006;85:183141.

[54] Hosseini V, Checkel MD. Reformer gas application in combustion onset control of hcci engine. The Journal of Engine Research. 2009;14, 1-23.

[55] Fuerhapter A, Unger E, Piock WF, Fraidl G. The new AVL CSI engine-HCCI operation on a multi cylinder gasoline engine. SAE Technical Paper No. 200401-0551; 2004.

[56] Dec JE, Sjöberg M. HCCI Combustion: The sources of emissions at low loads and the effects of GDI fuel injection. 8th Diesel Engine Emissions Reduction Workshop. 2002, p. 25-9.

[57] Kim DS, Lee CS. Improved emission characteristics of HCCI engine by various premixed fuels and cooled EGR. Fuel. 2006;85:695-704.

[58] Zhong S, Wyszynski M, Megaritis A, Yap D, Xu H. Experimental investigation into HCCI combustion using gasoline and diesel blended fuels. SAE Technical Paper No. 2005-01-3733; 2005.

[59] Carlucci A, De Risi A, Laforgia D, Naccarato F. Experimental investigation and combustion analysis of a direct injection dual-fuel diesel-natural gas engine. Energy. 2008;33:256-63.

[60] Hairuddin AA, Wandel AP, Yusaf T. Hydrogen and natural gas comparison in diesel HCCI engines-a review. Proceedings of the 2010 Southern Region Engineering Conference (SREC 2010): Engineers Australia; 2010.

[61] Saravanan N, Nagarajan G, Narayanasamy S. An experimental investigation on DI diesel engine with hydrogen fuel. Renewable Energy. 2008;33:415-21.

[62] Saravanan N, Nagarajan G, Sanjay G, Dhanasekaran C, Kalaiselvan K. Combustion analysis on a DI diesel engine with hydrogen in dual fuel mode. Fuel. 2008;87:3591-9.

[63] Verhelst S, Wallner T. Hydrogen-fueled internal combustion engines. Progress in Energy and Combustion Science. 2009;35:490-527.

[64] Kong S-C. A study of natural gas/DME combustion in HCCI engines using CFD with detailed chemical kinetics. Fuel. 2007;86:1483-9.

[65] Szwaja S, Grab-Rogalinski K. Hydrogen combustion in a compression ignition diesel engine. International Journal of Hydrogen Energy. 2009;34:4413-21. 
[66] Tomita E. Dual fuel HCCI combustion-High octane and high cetane number fuels. International Journal of Engine Research. 2005;6:453-63.

[67] Tomita E, Kawahara N, Piao Z, Fujita S, Hamamoto Y. Hydrogen combustion and exhaust emissions ignited with diesel oil in a dual fuel engine. SAE Technical Paper No. 2001-01-3503; 2001.

[68] Tomita E, Kawahara N, Piao Z, Yamaguchi R. Effects of EGR and early injection of diesel fuel on combustion characteristics and exhaust emissions in a methane dual fuel engine. SAE Technical Paper No. 2002-01-2723; 2002.

[69] Liu C, Karim GA. A simulation of the combustion of hydrogen in HCCI engines using a 3D model with detailed chemical kinetics. International Journal of Hydrogen Energy. 2008;33:3863-75.

[70] Saravanan N, Nagarajan G. An experimental investigation on hydrogen fuel injection in intake port and manifold with different EGR rates. International JOurnal of Energy and Environment. 2010;1:221-48.

[71] Rahman MM, Hamada KI, Kadirgama K. Heat transfer of intake port for hydrogen fueled port injection engine: A steady state approach. International Journal of Physical Sciences. 2011;6:4036-43.

[72] Rahman MM, Mohammed MK, Bakar RA. Effects of air fuel ratio and injection timing on performance for four-cylinder direct injection hydrogen fueled engine. European Journal of Scientific Research. 2009;25:214-25.

[73] Akansu SO, Dulger Z, Kahraman N, Veziroğlu TN. Internal combustion engines fueled by natural gas - hydrogen mixtures. International Journal of Hydrogen Energy. 2004;29:1527-39. 